Поспслов Олег Олександрович, аспірант Київського національного університету театру, кіно і телебачення iм. I. К. Карпенка-Карого ORCID 0000-0002-4171-3678 duopospelov@gmail.com

\title{
ЦИРКОВІ ВИСТАВИ У ЛЬВОВІ ТА ЧЕРНІВЦЯХ 1860-х рp.
}

Мета дослідження полягає у виявленні основних тенденцій розвитку циркового мистецтва та циркової справи у 1860-ті рр. та впливу на них політичних та економічних чинників на Буковині та у Східній Галичині. Методологія дослідження полягає в застосуванні історичного, історико-порівняльного, біографічного методів для максимально повного висвітлення функціонування циркової справи у 1860-х рр. на західноукраїнських землях. Наукова новизна полягає в тому, що автор вперше звертається до невідомих сторінок історії циркових та акробатичних виступів у провідних культурних центрах західноукраїнських земель у складі Імперії Габсбургів - міст Львова та Чернівців. В рамках дослідження автором знайдено, систематизовано, перекладено та використано матеріали німецької, польської та русинської преси 1860-х рр. та циркові афіші $з$ бібліотек Польщі (Бібліотека Ягеллонського університету), Австрії (Австрійська національна бібліотека) та низки університетських бібліотек США, які вперше введено до наукового обігу. У висновках виявлено особливості розвитку циркових мистецтв, розглянуто вплив політичних та соціальних перетворень в Імперії Габсбургів на циркову справу, проведено порівняльні паралелі між суспільним сприйняттям цирку і висвітленням циркових виступів у львівській та чернівецькій пресі досліджуваного періоду.

Ключові слова: цирк, циркове мистецтво, кінний цирк, циркові акробати, гімнасти, Львів, Чернівці, Галичина, Буковина.

Поспелов Олег Александрович, аспирант Киевского национального университета театра, кино и телевидения им. И. К. Карпенко-Карого

Цирковые представления во Львове и Черновцах 1860-х гг.

Цель статьи состоит в выявлении основных тенденций развития циркового искусства и циркового дела в 1860-е гг. и влияния на них политических и экономических факторов на Буковине и в Восточной Галичине. Методология исследования заключается в применении исторического, историко-сравнительного, биографического методов для максимально полного освещения функционирования циркового дела в 1860 -х гг. на западноукраинских землях. Научная новизна заключается в том, что автор впервые обращается к неизвестным страницам истории цирковых и акробатических выступлений в ведущих культурных центрах западноукраинских земель в составе Империи Габсбургов - городах Львове и Черновцам. В рамках исследования автором найдены, систематизированы, переведены и использованы материалы немецкой, польской и русинской прессы 1860-х гг., а также цирковые афиши из библиотек Польши (Библиотека Ягеллонского университета), Австрии (Австрийская национальная библиотека) и ряда университетских библиотек США, которые впервые введены в научный оборот. В выводах выявлены особенности развития цирковых искусств, рассмотрено влияние политических и социальных преобразований в Империи Габсбургов на цирковое дело, проведены сравнительные параллели между общественным восприятием цирка и освещением цирковых выступлений в львовской и черновицкой печати исследуемого периода.

Ключевые слова: цирк, цирковое искусство, конный цирк, цирковые акробаты, гимнасты, Львов, Черновцы, Галичина, Буковина University

Pospelov Oleg, a graduate student of The Kyiv National I. K. Karpenko-Kary Theatre, Cinema and Television

The Circus performances in Lviv and Chernivtsi in the 1860s.

The Purpose of the article is to identify the main trends in the development of the Circus arts and the Circus business in the 1860s. and to define the influence of political and economic factors in Bukovina and in Eastern Galicia on them. The Methodology is to use the historical, historical-comparative, biographical methods to maximize the description of the functioning of the Circus during the period of the 1860s. in the Western Ukrainian lands. The Scientific Novelty. The author for the first time ever opens the unknown pages of the history of the Circus and Acrobatic performances in the two main cultural centers of the Western Ukrainian lands at the time that they were a part of the Hapsburg Empire - the cities of Lviv and Chernivtsi. As part of the study, the author has discovered, systematized, translated and used the materials from the German, Polish and Ruthenian press of the 1860s, as well as circus posters from the libraries of Poland (Jagiellonian University in Kraków), Austria (Austrian National Library) and a number of US university libraries, which are being deployed into scientific circulation for the first time. In the Conclusions, the peculiarities of the development of the Circus arts have been revealed, and the influence of the political and the social reformation in the Hapsburg Empire on the Circus have been considered. The comparative

(C) Поспєлов О. О., 2019 
parallels between the public perception of the Circus and the coverage of the Circus performances in Lviv and Chernivtsi press of the described period have been made.

Key words: circus, circus art, equestrian circus, circus acrobats, gymnasts, Lviv, Chernivtsi, Galicia, Bukovina

Актуальність теми дослідження. Зважаючи на значне місце, яке посідає циркове мистецтво у сучасній українській культурі, актуальним $є$ питання вивчення історії розповсюдження, становлення та укорінення мистецтва цирку на етнічних теренах України, а також особливостей розвитку циркового мистецтва у культурних центрах на Сході та Заході України у різні історичні періоди. На особливу увагу заслуговують циркові вистави на західноукраїнських землях в часи їх перебування у складі Імперії Габсбургів, які досі не були предметом аналізу ані вітчизняних, ані зарубіжних науковців.

Аналіз досліджень і публікацій. На сьогоднішній день не існує жодного дослідження присвяченого цирковим та акробатичним виставам на західноукраїнських землях у другій половині XIX ст. Циркові виступи у Львові згадувалися польськими дослідниками, зокрема Станіславом Шнюр-Пепловським [51] в контексті висвітлення історії польського театру, втім акцент робився виключно на проблемі конкуренції цирку для театральних постановок. При цьому досі не робилося спроб мистецтвознавчого аналізу циркових виступів. Джерельною базою пропонованого дослідження $€$ матеріали чернівецької та львівської преси досліджуваного періоду.

Мета дослідження полягає у виявленні особливостей розвитку циркового мистецтва та циркової справи у 1860-ті pp. та впливу на них політичних та економічних чинників на Буковині та у Східній Галичині.

Виклад основного матеріалу. До початку 1860-х pp. львів'яни, нарівні 3 мешканцями провідних європейських міст, були обізнаними у найсучасніших тенденціях розвитку видовищних «циркових» мистецтв. У попереднє десятиліття Львів відвідали кращі циркові трупи Європи під керівництвом Е. Беранка, Е. Ренца, В. Шлезака, К. Гінне, В. Карре; на сцені львівського театру виступив відомий мім Едуард Клішніг. Вистави цирків і акробатичні вистави у театрах збирали повні зали, їх описували у пресі, визнаючи високий рівень майстерності провідних артистів Свропи.

Водночас із зацікавленістю і потребою львів'ян у циркових виставах, в культурному просторі Галичини поступово назрівала проблема, пов'язана із конкуренцією, яку представляв цирк для польського театру, і на чому постійно і наполегливо наголошувала патріотично налаштована інтелігенція, яка переймалася збереженням польської самоідентифікації серед широких верств суспільства. В цьому сенсі виховні та просвітницькі функції були покладені саме на театр. Втім цей конфлікт інтересів мав скоріше економічне та політичне підгрунтя, адже художні якості циркових вистав і майстерність артистів, особливо наїзників, не викликали нарікань критиків. До того ж, запрошені акробати брали участь в інтермедіях під час вистав польського театру.

Згідно даних популярної енциклопедії, виданої у Парижі 1860 року, населення Львова в середині XIX ст. складало 80,000 мешканців, з яких майже третину $(25,000)$ складали євреї [34, 234]. Це була значна потенційна аудиторія для циркових вистав.

Слід нагадати, що 1857 року Ернст Ренц побудував у Львові, у Єзуїтському Саду, вражаючий цирк на кілька тисяч місць $[46,1]$. Після закінчення гастролей Цирку Ренца ця споруда залишилася $\mathrm{i}$ використовувалась трупами, які прибували 3 гастролями до Львова, у наступні роки. Перед черговими виступами приміщення приводилося до ладу, декорувалося. Наявність стаціонарної будови значно полегшувало організаційні аспекти гастролей циркових колективів у місті.

6 травня 1860 року у Львові, у Цирку в Саду Сзуїтів відбулася перша вистава «різних умінь і сили» Леона Баєра, «першого польського атлета» і «першої моделі красних мистецтв Парижу, Дрездена та Берліна» та його трупи. Афіша повідомляла, що у першому відділенні програми демонструвалися військові тренування з залізним прутом вагою у 100 фунтів; «Ілійські ігри»у виконання Л. Баєра 3 двома дітлахами; велика презентація сили Л. Баєра 3 50-ти фунтовими вагами (гирями). У другому відділенні: - «Іспанський стілець», велика презентація Леона Байєра; «Ікарські ігри» у виконанні Леона Баєра та двох дітей; презентація майстерного балансу (еквілібру) у виконанні пані Баєр; «Samzon», або сила волосся: атлет мав нести 200 фунтів на своєму волоссі, чого до цих пір ніхто з виконавців в Європі ніколи не робив (!?); «Іспанський млин» у виконанні пана Х. Чюсепі (H. Ciusepi); «Тріумф Геркулеса»: камінь вагою у три центнери мав розбитися на грудях Л. Баєра. На закінчення - Велика презентація на французькій мотузці у виконанні пана Х. Чюсепі. У хвилини відпочинку грав живий оркестр. Також, Леон Баєр запрошував львів'янам позмагатись 3 ним у двобої з боротьби і пропонував охочим залишити своє ім'я та адресу у касі цирку [1]. 8 травня програма урізноманітнилась презентацією «сили нервів» 8-річної Анни Баєр, яка мала нести центнер 
ваги, чого жодна артистка ніколи не робила раніше. Під час «Тріумфу Геркулеса» на груді Л. Баєра встановлювали ковадло вагою у три центнери і кували на ньому залізо до такого ступеня гарячності, що шановна публіка могла заплювати об нього цигарки. Також, пан Чюсепі представив баланс на 4-х пляшках шампанського, та Леон Байєр демонстрував «силу щелеп»: 4 найсильніші чоловіки не могли зрушити атлета 3 місця. На закінчення вистави пан Чюсепі балансував на міцно натягнутій мотузці [2]. Також, під час однієї з вистав Леон Баєр виконував номер на трапеціï [5].

Виклик помірятися силою з Леоном Баєром прийняв львів'ян, м'ясник на ім'я Антоніо Інгле. Поєдинок 13 травня, під час якого суперники боролися у двох раундах по 10 хвилин, не виявив переможця, і двобій за приз у 25 золотих дукатів було продовжено 17 травня в одному з відділень вистави на дохід балансера Х. Чюзепі [3]. Однак, і цього разу не було виявлено переможця, отже 20 травня відбувся черговий, останній двобій. Окрім боротьби були представлені різні силові та акробатичні номери, а на завершення вистави було представлено велику комічну пантоміму у виконанні всіх членів трупи [4]. Про результати бою між Л. Баєром і А. Інгле писала спеціалізована віденська театральна газета «Wiener Theaterzeitung»: «В той час як боксерські поєдинки в Англії привертають увагу обох частин Світу (мається на увазі Свропа та Америка), у Львові, непоміченим для всього Світу, відбувся двобій 3 боротьби між «Геркулесом» Леоном Баєром (польським ізраїльтянином)» та місцевим м'ясником на ім'я Інгле за приз у 25 золотих дукатів. Більше того, гільдія місцевих м'ясників прагнула розпалити мужність свого чемпіона, пообіцявши заплатити йому значну суму, якщо він вийде переможцем. Двічі результат бою залишався невизначеним; лише втретє (20 травня) «Геркулесу» вдалося збити свого супротивника, якого треба було виносити 3 поля битви найгіршим чином. I бездушний натовп підбадьорював огидне видовище гучними оплесками! Відомо, що місцеве відділення поліції заборонило продовження таких змагань з боротьби» $[55,478]$.

Акробатичні і атлетичні вистави «силачів», які піднімали вагу і викликали місцевих мешканців позмагатися за приз у боротьбі відбувалися у Львові і в минулі десятиліття: найбільш значимими були виступи трупи Карла Раппо (1838) та трупи Жана Дюпюї (1836 та 1844 рр.). Такі вистави завжди були популярними і збирали численну аудиторію.

У жовтні 1862 року у Цирку в Сзуїтському Саду відбувалися вистави трупи акробатів, атлетів і гімнастів під дирекцією Франциска Віницького (Franciszka Winickiego) [28, 918].

На початку 1860-х pp. у Галичині була побудована і почала функціонувати «Галицька залізниця імені Карла Людвіга» [7, 184]. Це значно полегшувало пересування, зокрема, і великих циркових труп. Так, у травні 1963 року окремим потягом до Львова прибув Цирк Вільгельма Карре. Трупа налічувала 110 артистів та 75 коней, 3 яких було 40 «шкільних коней» (нім. Schulpferde), навчених за визнаним кращим методом. Цикл вистав передбачав покази мистецтва вищої школи верхової їзди, а також кінної дресури та гімнастики під керуванням власного художнього керівника (нім. Kunstdirector). Музичний супровід виконувався власною капелою музикантів. Трупою були представлені Паризькі Квадрильї, Балети Квітів, Маневри, Стипль-чези (долання перешкод верхи), пантоміми пішки і верхи, гімнастичні та акробатичні номери у виконанні видатних артистів найвищого рівня майстерності в елегантному вбранні. Вистави відбувалися у зі смаком декорованому цирку в Сзуїтському Саду. Приміщення цирку освітлювалось газом [36, 398].

21 травня Карре представив публіці велику історичну пантоміму «Вигнання Мазепи в Україну» (нім. Die Verbannung Mazeppa's in die Ukraine) [37, 436]. Примітним $\epsilon$ той факт, що саме в цей час на землях колишньої Речі Посполитої, що відійшли до Російської імперії, а саме в Царстві Польському, Північно-Західному краї і на Волині відбувалися драматичні події Польського повстання. Англійській кореспондент Генрі Едвардс згадував виставу про Мазепу у Цирку Карре у книзі «Приватна історія польського повстання з офіційних та неофіційних джерел». Він писав, що Львів був наповнений повстанцями, які прагнули потрапити на Волинь, і сцени з «Мазепи» водночас розважали їх і інструктували з приводу потрапляння до України. Шансів на це, насправді, у них було небагато, адже в околицях Львова проживали вороже налаштовані до поляків русинські селяни [43, 77]. 3 рекламних оголошень відомо, що 23 травня відбувся бенефіс наїзниці Клари Раш (Frl. Clara Rasch) [38, 442]; 30 травня - велика вистава і бенефіс братів Адольфа та Оскара Карре (синів директора В. Карре) [39, 464]; 10 червня - показ великої вистави-пантоміми «Лісовий монстр, або: Руйнування Фламменбурга» [40, 504]. Окрім вистав у цирку, трупа Карре взяла участь у стилізованих «Давньоримських перегонах», які проводилися на новозбудованому великому Іподромі. Передбачалися призи для переможців [39, 464].

Один 3 польських оглядачів після відвідин Цирку Карре зауважив, що не помітив там нічого цікавого, окрім розкішних хвостів у коней, жаліючись що на львівських вулицях він бачив лише 
коней $з$ по коліна обрізаними хвостами, в той час як у давній Польщі сидіти на коні з відрізаним хвостом вважалося ганьбою і приниженням дворянської гідності $[49,3]$.

Також, русинська газета «Вьстник» (Урядовий часопис для русинів австрійської держави), яка видавалася у Відні, писала, що як тільки Цирк Карре виїхав 11 липня зі Львова, то вже Цирк Ренца з Пешту подав прохання туди заїхати, і начебто «забагато буде и нас комедіантства» $[6,3]$. Однак, ймовірно, навіть Ренцу відмовили у дозволі: у Львові його трупа не виступала.

У листопаді 1863 року, у виставах Менажерії Августа Шольца, яка розміщувалась на площі Голуховського у Львові, були задіяні леви, тигри пантери, леопарди і гієни $[41,1076]$. На закінчення демонструвалася сцена «Daniel in der Löwengrube» («Данило в лігві лева»), під час якої дресирувальник заходив у клітку і годував усіх звірів $[42,1112]$.

Циркові виступи середини XIX ст. у Чернівцях були менш висвітленими у тогочасній австрійській пресі, ймовірно, через меншу значимість столиці Буковини у порівнянні з іншими культурними осередками Імперії Габсбургів, втім достеменно відомо, що циркові трупи час від часу навідувалися до міста. Кілька австрійських джерел описують пожежу, яка сталася 4 грудня 1853 року під час гастролей Цирку Беранка і не на жарт перелякала численну публіку, що зібралася на виставі. Одна з газет писала, що причиною загоряння була піч, яка опалювала приміщення цирку [47, 1374]. Технічні можливості опалювання цирків у зимовий період у XIX ст. перебували на досить низькому рівні, і такі прикрі інциденти час від часу траплялися з цирками у різних містах різних країн. Інша газета писала, що причиною був недопалок цигарки, яку палив один із глядачів [48, 1166]. Втім, цікавим є сам факт зимових гастролей Цирку Беранка у Чернівцях одразу після виступів восени 1853 року у Львові. Рівень майстерності артистів та підбір коней у цій трупи визнавався критиками рівним Цирку Франконі у Парижі [27б 788].

У Чернівцях, за даними польського видання 1864 року, проживало 40000 жителів. Зазначалося, що в той час чернівчан розважали польський, румунський, німецький театри; італійська опера і трупа майстерних наӥзників (!). Однак всього цього було недостатньо, і очікувалося відкриття руського театру [33, $143-144]$.

На початку літа 1865 року газета «Bukowina» писала, що з Трансільванії надходили чутки, начебто найближчим часом до Чернівців мав завітати відомий Цирк Ренца, який планував гастрольну подорож до Галичини $[9,2]$. Однак плани ці так і залишилися нереалізованими, і Цирк Ренца після єдиних гастролей у Львові 1857 року більше ніколи не відвідував Галичини та Буковини. 9 червня та сама газета сповіщала, що до Чернівців прибув секретар «Олімійського Цирку» (як він сам себе називав) Джузеппе Саффаро для будівництва цирку для гастролей трупи пана Соботти (40 артистів i 20 коней), виступи якої мали розпочатися найближчим часом [10, 2].

Директорами трупи, яка прибула до міста в середині червня, були італійські акробати 3 Мілану Ігнат Соботта та Теодор Сідолі $[44,113]$. Вони не жаліли коштів для побудови $\mathrm{i}$ облаштування приміщення цирку. Одразу після прибуття розпочалися тренування з виїздки коней, давалися уроки верхової їзди, проводилися заняття з гімнастики та боротьби. Реклама обіцяла багату та різноманітну програму $[11,2]$.

Вистави у «Цирку Соботти та Сідолі» (Cirkus Sobotta und Sidoli) розпочалися 17 червня. Особливий інтерес викликали «ікарійські ігри» та баланс на канаті у виконанні «Блондіна II» та маленьких «блондинчиків» $[12,2]$. Тут слід пояснити, що Блондін (справжнє ім'я - Жан-Франсуа Гравеле), з яким порівнювали артистів, здобув визнання, здійснивши 1859 року перехід по канату через Ніагарський водоспад [50,24], і цим «подарував друге життя» древньому жанру балансування на мотузці, який не вважався чимось оригінальним і демонструвався як на міських площах, так i, 3 другої половини XVIII ст., під час циркових вистав. Вправи на канаті, продемонстровані балансерами у Чернівцях здавалися незбагненними! На визнання заслуговували і виступи майстерних наїзників. Хоча у перших виставах задіяно було лише 11 коней, зазначалося, що трупа мала чим дивувати, $\mathrm{i}$ програма могла оновлюватись кожного дня протягом декількох тижнів. Дещо зіпсувала настрій лише несприятлива дощова погода $[12,2] .22$ червня відбувся бенефіс гротескового та силового наїзника (Grotesque- und Parforce-Reiters) Йозефа Ганушека, під час якого артисти виступали у вишуканих нових костюмах. 25 червня пан Вольта продемонстрував рідкісний силовий номер під назвою «Іспанський потяг». Всі артисти трупи демонстрували високу майстерність у верховій їзді та гімнастиці, особливо виділялися пп. Сидолі, Вольта, Ганушек, Соботта, клоун, діти Йозеф і Марі. 26 червня відбувся останній виступ. Трупа рушила до Галичини для двотижневих виступів під час ярмарку (ринку) у Лошківцях (нім. Laszkowce), а потім мала повернутися до Буковини і продовжити вистави у Чернівцях $[13,3]$. 
В середині липня Соботта і Сідолі, як і планувалося, повернулися до Чернівців. «Bukowina» писала, що «вони робили все можливе, щоб показати відвідувачам цирку нові, ще не побачені трюки в області мистецтва балансування на канаті. Вражаючі виступи дітлахів, які дивували легкістю $\mathrm{i}$ безпечністю у найнебезпечніших позиціях та стрибках, не залишали бажати кращого» $[14,3]$.

У серпні про трупу наїзників у складі 40 артистів та 30 коней під дирекцією пп. Соботти та Сідолі згадувала i «Gazeta Lwowska». Повідомлялося, що товариство виступало у Тарнополі. У програмі також були задіяні дресировані собаки. Вистави були цікавими, а ціни на квитки дуже поміркованими. За кілька днів трупа вирушала до Бродів у напрямку Львова $[29,753]$. Однак, наразі немає жодних документованих підтверджень виступів цієї трупи у Львові. Ймовірно, уряд Львова відмовив у дозволі виступати у місті.

1866 року на сцені львівського театру виступали американські акробати Елліс, Найс, Беррі і Ліч (Akrobaten Hrn. Ellis, Nice, Berry and Leach). Вони брали участь у кількох виставах німецького театру [30, 340]. Виступи акробатів викликали здивування, а їх художні успіхи не поступалися касовим зборам. Серед одноактних п’єс, які представило це товариство, оглядач віденської театральної газети особливо відзначив виставу «Орендар i перукар», однак зауважив, що ці акробатичні виступи відволікали увагу публіки від нових артистичних сил, залучених до німецької трупи $[54,2]$. Також, 1866 року на сцені Театру гр. Скарбека виступав «перший акробатичний виконавець 3 Парижу» (erster acrobatischer Künstler aus Paris) з трьома собаками пан Меєргатте (Herr Meergatte) $[52,10-11]$.

У січні 1867 року у головній вартовій башті Львова відбулася вистава вартових протипожежної команди Львова, про яку писала «Gazeta Narodowa». Тридцять п'ять охоронців представили гімнастичні та акробатичні композиції, зокрема, номери на батуті, на шнурі (мотузці), на трапеції; вольтижування на кобилі; піднімали півцентнерові ваги; будували акробатичні фігури у повному вбранні. Виступали групами та поодинці для численної публіки, яка нагороджувала виконавців гучними оплесками. Серед гостей були представники міської Ради та магістрату, журналісти та військові $[32,2]$, що свідчило про високий суспільний статус заходу і $є$ показовим прикладом популярності акробатики серед львів'ян у 1860-ті рр., у часи коли, запроваджуючи протекційні заходи щодо польського театру, влада міста не дозволяла професійним цирковим трупам виступати у Львові. Водночас, факт подібної вистави доводив, що для виконання акробатичних номерів не обов'язково було бути професійним артистом цирку.

На початку листопада 1867 року до Чернівців прибув «Цирк Хюттемана» (Circus Hüttemann), який перед цим виступав у Яссах. Відомо, що директор Густав Хюттеман разом із компаньйоном Вільгельмом Суром, на початку 1860-х pр. успішно гастролював в багатьох австрійських та німецьких містах з Цирком Сура і Хюттемана (Circus Suhr \& Hüttemann). Була в їхньому репертуарі і пантоміма «Мазепа» $[45,4]$. У Чернівцях трупа налічувала 50 артистів та 40 коней найшляхетніших порід. Справжньою дивиною обіцяв бути живий слон $[15,2]$.

Цирк у Чернівцях був майстерно побудований під керівництвом і наглядом секретаря компанії пана Фастенберга. Споруда відмінно відповідала всім вимогам і була зручною і комфортною для відвідувачів. Перші три вистави відбулися у вщент заповнених залах. Вистави відзначалися вдалим музичним супроводом, блискучою майстерністю артистів у верховій їзді та гімнастиці, вишуканими костюмами та підготовкою коней. В інтервалах між номерами публіку розважали клоуни. В трупі особливо виділялася пані Поліна, яка була кращою наїзницею в трупі Ренца під час виступів у Відні, Петербурзі та інших столицях, а також гротесковий та силовий наїзник Франц Дубські $[16,2]$.

Наступні вистави здивували аудиторію новими постановками. Чудово виступали жінки: Анна, Ліна Дубські та Станек i, особливо, майстриня шкільної їзди пані Поліна. Пан Сміт відзначився блискучим перетворенням в образ Юлія Цезаря, а пан Ріккобено, як гротескний та силовий наїзник. Оригінальними та надзвичайно складними, втім виконаними 3 неймовірною легкістю, були досягнення в гімнастиці, продемонстровані клоунами Скроггсом та Пікарді, паном Ламбергером в антре на ходулях, паном Артуром у номері «каучук» (нiм. der Kautschukmann), братів Пікарді на турніку. Успіх був надзвичайним. Найгучніші овації лунали для малого, але сміливого і вмілого наїзника Франца Дубські. Чудовим був дуетний показ школи верхової їзди директором п. Хюттеманом та Міс Поліною. Ще до виступу загальну напругу викликала поява двох китайських артистів, які представили національне мистецтво метання ножів. Багато аплодисментів отримали аравійський сірий жеребець «Бібі» та, особливо, слон «Тоні» $[17,2]$.

Наприкінці листопада приміщення цирку почало опалюватись. Окрім виступів наїзників, в яких незрівнянними були Поліна Фастенберг, Луїс Дубські та сам директор Хюттеман, гімнастичних 
і танцювальних номерів, особливе враження справляли китайці, виступ яких викликав уявлення про Ринок у Пекіні $[18,3]$.

У черговій замітці оглядач газети «Bukowina» задавав питання читачам чи повинен він описувати враження від яскравого вечора на виставі у Цирку Хюттемана, чи краще було на власні очі побачити слона на китайському ярмарку, китайських комедіантів та метальників ножів, жонглерів, танцівників і танцівниць, повітряних та партерних гімнастів, відмінні пантомімічні вистави з їхніми еволюціями і битвами пішки і верхи? Чи мав глядач у власних ескізах зобразити граціозні прояви незрівнянної майстерності Поліни Фастенберг і дивуватися небезпечними і небаченими трюками, бездоганно виконаними родиною Дубських, так само як захоплюватися вміннями інших численних артистів трупи, зокрема дітлахів? Дійсно, потрібно було особисто відвідати виступ, щоб відчути атмосферу і переконатися, що вистави були надзвичайними. 26 листопада вперше було представлено пантоміму «Фра Диявол», в якій взяла учать уся трупа. Також, пан Хюттеман відкрив курси для бажаючих навчатись верхової їзди $[19,2]$. Останні вистави у Чернівцях відбулися в середині грудня i були дуже успішними. Далі трупа прямувала до Львова [20, 2].

У Львові взимку проходив Карнавал, і саме тому цирковій трупі було дозволено виступати у місті. Львівська преса майже повністю ігнорувала вистави Цирку Хюттемана, і лише у лютому 1868 року «Dziennik Lwowski» надрукував замітку, що Карнавал у Львові ряснів безліччю приватних та публічних забав, та не зважаючи на музичні концерти та драматичні вистави, Цирк Хюттемана майже щоденно заповнювався глядачами, які були у захваті від слона, майстерності пані Дубської та клоунів. Вистави у цирку Хуттемана заслуговували на увагу громадськості, адже його трупа складалася 3 умілих вершників, які виконували карколомні трюки, стрибунів і гімнастів, які викликали здивування глядачів, i багато політиків могли б позаздрити таким вишуканим кульбітам. Коней було небагато, але вони були добре навчені. Якщо додати до цього слухняність слона своєму вихователеві, то не дивно, що глядачі охоче йшли до цирку [35, 3].

Також, варшавський «Tygodnik Ilustrowany» писав, що Цирк Хюттемана з численною трупою вносив різноманітність у життя Львова і спустошував гаманці громадян. Особливо вражала спритність двох китайців у національному мистецтві метання ножів та вчений слон. Кожного дня відбувалося дві вистави, і ці дві атракції демонструвалися окремо у різних виставах, і той хто вдень побачив слона, мав купити квиток, щоб вечорі побачити виступ китайців. Також, влаштовувалися окремі вистави для дітей. Винахідливість пана Хюттемана була невичерпною у вигадуванні спокус, які викликали зацікавленість публіки і приносили йому прибуток [53, 98].

У липні 1869 року, після виступів у Варшаві, до Львова прибула трупа арабських гімнастів під керівництвом Сіді Ель Хадж Алі бен Мохаммеда і протягом двох тижнів виступала на сцені Театру гр. Скарбека $[31,1023]$. Про те якими були вистави цієї трупи дізнаємось вже з чернівецької преси, адже після виступів у Львові, у серпні 1869 року арабська акробатична трупа з Північної Африки «Бені-Зуг-Зуг» (Beni-Zoug-Zoug) завітала до Чернівців. Сповіщалося, що 40 акробатів прибули 3 самої пустелі Сахара. 3 австрійських міст, де вже встигнула виступити ця компанія, надходили рекомендації, що у гімнастичному та акробатичному мистецтві ще не робилося нічого подібного: піраміди 3 тіл, біг, стрибки і падіння були настільки ж чудовими і дивовижними, як і сама тропічна пустеля, і у своїй стихії ця бурхлива енергія була величною, потужною і дивною; але те, що сприяло найвищому ступеню естетичного задоволення, - це витончена легкість, яка характеризувала всі їхні розумні та яскраво складені вистави [21,2 - 3].

Виступи відбувалися в театральному залі «Hotel de Moldavie» [22, 5] і мали приголомшливий успіх. Нічого подібного у Чернівцях ще не бачили $[23,2]$. Критик не був скупим на епітети: усі рухи ці діти пустелі виконували з неймовірною швидкістю і спритністю, вони дійсно робили дивні речі у гімнастичному та акробатичному жанрі; були легкими як газелі, сильними як леви, рухливими як пантери і стрибучими як тигри; вражали харизмою і кількістю. Найбільш вражаючими були людські піраміди, які навряд чи можна перевершити. Аудиторія приймала всі виступи нероздільними оплесками, особливо, маленьких артистів, чиї витончені рухи справили найприємніше враження на глядачів $[24,2]$. Те, що демонстрували африканські артисти важко було описати. На сцені оживала Легенда про Геракла: старий тримав сімох чоловіків на плечах голові та у кожній руці. Піраміди, стовпи і тріумфальні арки будувалися з матеріалу красивих, струнких чоловічих фігур, які досягали софітів сцени [25, 2].

Виступи трупи африканських акробатів тривали до кінця літа. Програма постійно змінювалась. На одній з вистав стався трагічний випадок: 38-річний артист отримав серйозну травму i помер у лікарні $[26,2]$. За видимою легкістю і намаганням вразити аудиторію ховалися ризик $\mathrm{i}$ нехтування власною безпекою. Втім, саме небезпека i ризик, притаманні акробатичним i 
гімнастичним номерам, вабила до цирку широку аудиторію. Під час виконання найскладніших номерів не завжди вдавалося запобігти найгіршого розвитку подій.

Отже, спостерігалася відмінність поглядів на циркові вистави у чернівецькій та львівській пресі. У Чернівцях - детальні описи і шанобливі відгуки, у Львові - стислі коментарі, подекуди 3 саркастичним підтекстом. При цьому в обох містах відзначалася значна відвідуваність виступів $\mathrm{i}$ незаперечно визнавався талант артистів.

Висновки. Наслідки революційних подій кінця 1840-х pp. та прийняття 1861 року нової Конституції в Австрії сприяли «демократизації» суспільства i значному розширенню прав національних громад в багатонаціональній Імперії Габсбургів. У 1860-ті pp. у Львові почали зміцнюватися пропольські настрої, з'явилася польська влада [8]. Це мало особливий вплив на циркову справу у Галичині, з огляду на те, що протягом тривалого періоду циркові трупи, які відвідували Львів, складали конкуренцію для місцевого польського театру. Отже поляки отримали реальні можливості регулювання культурної політики задля захисту свого театру. Попри те, що за право виступів у місті циркові підприємці сплачували чималі грошові внески у міський бюджет, i їх трупи обов'язково давали вистави, кошти від яких передавалися на благодійні потреби, цирки чимало заробляли, і прибутки їх значно перевищували витрати. I ці зароблені кошти вивозилися з міста. Такі суперечності між мистецтвом, економікою та політикою підказували уряду міста рішення щодо обмежень гастрольної діяльності цирків. Звісно, повністю заборонити циркові вистави навіть найсуворіші керманичі були не в змозі, адже у суспільстві існувала потреба у видовищах та розвагах, i цирк задовольняв ці потреби найкращим чином, а будь-які заборони в усі часи лише підігрівали інтерес до об'єкту заборони. Так сталося і з цирком у Львові. В 60-ті рр. спостерігалося значне зниження висвітлення циркових вистав у польській пресі, цирки не виступали в місті по декілька років, але кожні гастролі завжди ставали очікуваною подією і збирали величезну аудиторію.

На Буковині ситуація різнилася з Галичиною через відсутність суттєвої проблеми конкуренції між гастрольними цирковими та місцевими театральними трупами і національних протиріч між різними громадами. Якщо львівська польськомовна преса другої половини $60-\mathrm{x}$ рp. XIX ст. майже повністю ігнорувала цирк і наголошувала на його негативному впливі на свідомість галицьких поляків, чернівецька німецькомовна преса об'єктивно висвітлювала чергові гастролі, акцентуючи увагу на художніх якостях циркових виступів. При цьому в обох містах виступали одні і ті самі трупи.

На думку автора, зниження інтересу преси до циркових вистав у 1860-ті рр. у порівнянні 3 публікаціями першої половини XIX ст. свідчить про зміни у сприйнятті цирку «інтелектуальним» прошарком суспільства. Якщо у львівській пресі 1830-х - 1840-х рр. відчувалося відношення до циркових виступів, як до складової художньої культури і витворів мистецтва або, принаймні, чогось надзвичайного, ефектного і оригінального, то у другій половині XIX ст. до трюків починали звикати, і циркові виступи вже не здавалися чимось неймовірним. Цирк ставав, більшою мірою, місцем розваг для широкої публіки, ніж асоціювався з мистецтвом. Однак, змінювалось і саме суспільство $\mathrm{i}$ навколишній світ, чому сприяла індустріалізація і науково-технічний прогрес. У військовій справі розвиток артилерії та вогнепальної зброї нівелював провідну роль кавалерії; покази витонченої майстерної верхової їзди втрачали провідну роль у циркових виставах, а отже змінювалось загальносуспільне відношення до мистецтва наїзників. Під час циркових показів глядачів потрібно було постійно дивувати і розважати чимось «новим». Цирк збагачувався новими жанрами, але, водночас, втрачав особливу привабливість, притаманну саме «кінному цирку» першої половини XIX ст. Важливим є той факт, що концепція циркового видовища, започаткована Філіпом Естлі, яка передбачала поєднання в межах однієї вистави показів майстерної верхової їзди та виступів балансерів і клоунів, сприяла естетизації виступів акробатів та комедіантів, які ще 3 часів Середньовіччя загалом негативно сприймалися у «вищому» суспільстві, і виявлялося це навіть у забороні виступів та переслідуванні подорожуючих гістріонів. Отже, після втрати провідної ролі наїзників у циркових виставах 1860-х рр. та початку розвитку та більш активного залучення до них саме акробатичних і гімнастичних жанрів, клоунади, підсвідоме негативне відношення до «комедіантства» почало знаходити прояв у сприйнятті «цирку» не як культурного явища та витвору мистецтва, а як видовищної розваги. Втім, публіки на циркових виставах було завжди вдосталь, директори отримували чималі прибутки, стаючи заможними громадянами, і вони навряд чи переймалися філософськими питаннями приналежності циркових показів до естетичних категорій «красних мистецтв».

Попри обмеження та заборони львівської влади, циркова справа на західноукраїнських землях у 1860-ті рр. функціонувала і розвивалися синхронно 3 рештою частин Імперії Габсбургів. 
Спостерігалося жанрове розширення і збагачення. У Чернівцях та у Львові будувалися циркові приміщення, чернівчани та львів'яни вперше побачили виступи китайців, акробатів з Африки. Окрім виступів майстерних наїзників, належну увагу преса приділяла акробатичним та гімнастичним номерам, клоунам.

Еволюція та розвиток концепції циркової вистави у 60-ті pp. XIX ст. робили іiі все більше схожою на «цирк», який ми бачимо сьогодні.

\section{Jimepamypa}

1. Афіша виступу трупи Леона Баєра у Львові (6 травня, 1860 р.). «Pierwsze wielkie przedstawienie Leon Baier $=$ Erste große Vorstellung Leon Baier». Lwów : Gedruckt bei M.F. Poremba, 1860. URL: https://jbc.bj.uj.edu.pl/publication/597985

2. Афіша виступу трупи Леона Басра у Львові (8 травня, 1860 р.). «Drugie wielkie przedstawienie Leon Baiera $=$ Zweite große Vorstellung Leon Baier». Lwów : Gedruckt bei M.F. Poremba, 1860. URL: https://jbc.bj.uj.edu.pl/publication/598067

3. Афіша виступу трупи Леона Баєра у Львові (17 травня, 1860 р.). «Wielkie przedstawienie różnych sztuk i siły Leona Baiera $=$ Vorstellung des Leon Baier». Lwów : Gedruckt bei M.F. Poremba, 1860. URL: https://jbc.bj.uj.edu.pl/publication/599705

4. Афіша виступу трупи Леона Баєра у Львові (20 травня, 1860 р.). «Wielkie przedstawienie Leona Baiera $=$ Vorstellung des Leon Baier». Lwów : Gedruckt bei M.F. Poremba, 1860. URL: https://jbc.bj.uj.edu.pl/publication/598736

5. Афіша виступу трупи Леона Баєра у Львові (травень, 1860 р.). «Große ausserordentliche Kunst und Kraft Vorstellung Leon Baier». Lwów: Gedruckt bei M.F. Poremba, 1860. URL: https://jbc.bj.uj.edu.pl/publication/598265

6. «ВЂстникъ». Часопісь урядова для русиновъ аустрійськои державы. 1863. Число 51. 15.07.

7. Мошенский, С. 3. Финансовые центры Украины и рынок ценных бумаг индустриальной эпохи. Львов: «пестрое пятно на карте Европы». Роль железнодорожных проектов в развитии рынка капитала. London: Xlibris, 2014. 503.

8. Пасічник Ю. В. Українські землі в складі Австрійської та Австро-Угорської імперії, Галичина. Бюджетна система України: Навчальний посібник. К.: Знання-Прес, 2006. 607 c. URL: https://pidruchniki.com/16330826/finansi/ukrayinski_zemli_skladi_avstriyskoyi_avstro-ugorskoyi_imperiy

9. «Bukowina». Zirkus Renz in Aussicht. 1865. Nr. 66. 04.06.

10. «Bukowina». Cirkus Sobotta. 1865. Nr. 68. 09.06.

11. «Bukowina». Die Vorstellungen im Zirkus. 1865. Nr. 71. 16.06.

12. «Bukowina». Cirkus Sobotta und Sidoli. 1865. Nr. 73. 21.06.

13. «Bukowina». Cirkus Sobotta und Sidoli. 1865. Nr. 75. 25.06.

14. «Bukowina». Die Vorstellungen im Zirkus. 1865. Nr. 84. 16.07.

15. «Bukowina». Circus Hüttemann. 1867. Nr. 128. 30.10.

16. «Bukowina». Circus Hüttemann. 1867. Nr. 135. 15.11.

17. «Bukowina». Circus Hüttemann. 1867. Nr. 136. 17.11.

18. «Bukowina». Circus Hüttemann. 1867. Nr. 139. 24.11.

19. «Bukowina». Circus Hüttemann. 1867. Nr. 140. 27.11.

20. «Bukowina». Circus Hüttemann. 1867. Nr. 145. 08.12.

21. «Czernowitzer Zeitung». 1869. Nr. 121. 06.08.

22. «Czernowitzer Zeitung». 1869. Nr. 123. 10.08.

23. «Czernowitzer Zeitung». 1869. Nr. 125. 13.08.

24. «Czernowitzer Zeitung». 1869. Nr. 126. 15.08.

25. «Czernowitzer Zeitung». 1869. Nr. 128. 18.08.

26. «Czernowitzer Zeitung». 1869. Nr. 137. 03.09.

27. «Gazeta Lwowska». 1853. Nr. 197. 30.08.

28. «Gazeta Lwowska». 1862. Nr. 229. 06.10.

29. «Gazeta Lwowska». - Towarzystwo jeźdźców sztucznych. 1865. Nr. 188. 18.08.

30. «Gazeta Lwowska». 1866. Nr. 80. 07.04.

31. «Gazeta Lwowska». 1869. Nr. 161. 17.07.

32. «Gazeta Narodowa». 1867. Nr. 14. 17.01.

33. Gwiazdka Cieszynska. Pismo poświecone wiadomosciom politycznym, nauce, przemysłowi i zabawie. 1864. Nr.18. 30.04.

34. Dictionnaire de la conversation et de la lecture inventaire raisonné des notions générales les plus indispensables à tous, par une société de savants et de gens de lettres. sous la direction de M. W. Duckett. Seconde édition. Tome douzième. Paris : librairie de Firmin Didot, Fils et Cie., imprimeurs de l'Institut, Rue Jacob, 56., M DCCC LX (1860). $800 \mathrm{p}$.

35. «Dziennik Lwowski». 1868. Nr. 37.14 .02$.

36. «Dziennik urzedowy do Gazety Lwowskiej». «Amtsblatt für Lemberger Zeitung». 1863. Nr. 104. 07.05. 
37. «Dziennik urzedowy do Gazety Lwowskiej». «Amtsblatt für Lemberger Zeitung». 1863. Nr. 115. 21.05.

38. «Dziennik urzedowy do Gazety Lwowskiej». «Amtsblatt für Lemberger Zeitung». 1863. Nr. 117. 23.05.

39. «Dziennik urzedowy do Gazety Lwowskiej». «Amtsblatt für Lemberger Zeitung». 1863. Nr. 122. 30.05.

40. «Dziennik urzedowy do Gazety Lwowskiej». «Amtsblatt für Lemberger Zeitung». 1863. Nr. 130. 10.06.

41. «Dziennik urzedowy do Gazety Lwowskiej». "Amtsblatt für Lemberger Zeitung».1863. Nr. 260. 13.11.

42. «Dziennik urzedowy do Gazety Lwowskiej». «Amtsblatt für Lemberger Zeitung».1863. Nr. 273. 28.11.

43. Edwards, Henry Sutherland - The Private History of a Polish Insurrection, from Official and Unofficial Sources., in Two Volumes: Vol. II. London : Saunders, Otley, and Co., 66, Brook Street, W., 1865. 290 p.

44. Ferdinand Roeder's Theater-Kalender auf das Jahr 1865. Berlin: Commissions-Verlag von W. J. Peiser. Friedrichsstraße 142., 1865. $589 \mathrm{~s}$.

45. «Isar Zeitung». 1862. Nr. 227. 18.08.

46. «Lemberger allgemeiner Anzeiger». Tagesblatt für Handel und Gewerbe, Kunst, geselliges Leben, Unterhaltung und Belehrung. 1857. Nr. 1. 02.04.

47. Neue Passauer Zeitung. 1853. Nr. 345.16.12.

48. Pressburger Zeitung. 1853. Nr. 288. 18.12.

49. «Przegląd». 1863. Nr. 17. 01.06.

50. Saltarino, Signor - Artisten-Lexikon : biographische Notizen über Kunstreiter, Dompteure, Gymnastiker, Clowns, Akrobaten, Specialitäten etc. : aller Länder und Zeiten / S. Saltarino. - Düsseldorf : Druck und Verlag von Ed. Lintz, 1895. - $316 \mathrm{~s}$.

51. Schnür-Pepłowski, Stanisław - Teatr polski we Lwowie (1780- 1881). Lwów: Skład główny w księgarni Gubrynowicza i Schmidta. z Drukarni „Dziennika Polskiego", 1889. 411 s.

52. Theater Almanach des k. k. priv. Graflich-Skarbeck'schen Theaters. Souvenir für das Jahr 1866 allen Freunden der Bühne in tiefster Ehrfurcht gewidmet VON Eduard Franz Schulz, Souffleur des deutschen Theaters Besitzer der silbernen Ehrenmedaille. Lemberg. Buchdruckerei von E. Winiarz. 1866. $46 \mathrm{~s}$. 8. 22.02 .

53. Tygodnik Ilustrowany. Tom I. Lwów, cyrk Huttemana: Władysław Zawadzki, Kor. T.I.1868. Nr.

54. «Wiener Theaterpost». Zeitschrift für Theater, Musik, Vereins-Interessen. 1866. Nr. 11. 20.04.

55. «Wiener Theaterzeitung». 1860. Nr. 121. 25.05.

\section{References}

1. The poster of Leon Baier and his troupe's performance in Lviv (May, $6^{\text {th }}$, 1860). «The first great performance Leon Baier». Lviv, 1860 / URL: https://jbc.bj.uj.edu.pl/publication/597985 [In Polish \& German]

2. The poster of Leon Baier and his troupe's performance in Lviv (May, $8^{\text {th }}, 1860$ ). «The second great performance Leon Baier». Lviv, 1860 / URL: https://jbc.bj.uj.edu.pl/publication/598067 [In Polish \& German]

3. The poster of Leon Baier and his troupe's performance in Lviv (May, $17^{\text {th }}, 1860$ ). «The great performance of different skills and strength Leon Baier». Lviv, 1860 / URL: https://jbc.bj.uj.edu.pl/publication/599705 [In Polish \& German]

4. The poster of Leon Baier and his troupe's performance in Lviv (May, 20 ${ }^{\text {th }}, 1860$ ). «The great performance of Leon Baier». Lviv, 1860 / URL: https://jbc.bj.uj.edu.pl/publication/598736 [In Polish \& German]

5. The poster of Leon Baier and his troupe's performance in Lviv (May, 1860). "Great Extraordinary Artistic and Power Performance Leon Baier». Lviv, 1860 / URL: https://jbc.bj.uj.edu.pl/publication/598265 [In German]

6. «Vestnik». The government magazine for the Ruthenians of the Austrian State. (1863). - Number 51. 15.07. Vienna [In Ruthenian]

7. Moshensky, S. Z. (2014). The Financial centers of Ukraine and the market of the Securities of the Industrial Age. Lviv: "a sharp spot on the map of Europe". The role of railway projects in the development of the capital market / London: Xlibris, 503. [In Russian]

8. Pasichnik Yu.V. (2006). Ukrainian lands in the Austrian and Austro-Hungarian empires, Galicia. The Budget System of Ukraine: Textbook. Kyiv: Knowledge-Press, 607. URL: https://pidruchniki.com/16330826/finansi/ukrayinski_zemli_skladi_avstriyskoyi_avstro-ugorskoyi_imperiy [In Ukrainian]

9. «Bukowina». (1865). Nr. 66. 04.06. [In German]

10. «Bukowina». (1865). Nr. 68. 09.06. [In German]

11. «Bukowina». (1865). Nr. 71. 16.06. [In German]

12. «Bukowina». (1865). Nr. 73. 21.06. [In German]

13. «Bukowina». (1865). Nr. 75. 25.06. [In German]

14. «Bukowina». (1865). Nr. 84. 16.07. [In German]

15. «Bukowina». (1867). Nr. 128. 30.10. [In German]

16. «Bukowina». (1867). Nr. 135. 15.11. [In German]

17. «Bukowina». (1867). Nr. 136. 17.11. [In German]

18. «Bukowina». (1867). Nr. 139. 24.11. [In German]

19. «Bukowina». (1867). Nr. 140. 27.11. [In German]

20. «Bukowina». (1867). Nr. 145. 08.12. [In German]

21. «Chernivtsi‘s Gazette». (1869). Nr. 121. 06.08. [In German] 
22. «Chernivtsi`s Gazette». (1869). Nr. 123. 10.08. [In German]

23. «Chernivtsi`s Gazette». (1869). Nr. 125. 13.08. [In German]

24. «Chernivtsi's Gazette». (1869). Nr. 126. 15.08. [In German]

25. «Chernivtsi's Gazette». (1869). Nr. 128. 18.08. [In German]

26. «Chernivtsi's Gazette». (1869). Nr. 137. 03.09. [In German]

27. «Lwowska Gazette». (1853). Nr. 197. - 30.08. [In Polish]

28. «Lwowska Gazette». (1862). Nr. 229. - 06.10. [In Polish]

29. «Lwowska Gazette». (1865). Nr. 188. - 18.08. [In Polish]

30. «Lwowska Gazette». (1866). Nr. 80. - 07.04. [In Polish]

31. «Lwowska Gazette». (1869). Nr. 161. - 17.07. [In Polish]

32. «National Gazette». (1867). Nr. 14. - 17.01. [In Polish]

33. «The Cieszyn Star». A magazine dedicated to political news, science, industry and fun. (1864). Nr. 18. 30.04. Cieszyn [In Polish]

34. The Dictionary of the conversation and the reading of reasoned inventory of the general notions most indispensable to all, by a society of scientists and educated people. under the direction of Mr. W. Duckett. Second edition. (1860). Twelfth Vol. Paris: Firmin Didot's bookstore, Fils et Cie, printers of the Institute, Rue Jacob, 56., 800. [In French]

35. «Official Lviv". (1868). Nr. 37.14.02. [In Polish]

German]

36. «The Official Journal for the Lwowska Gazette». (1863). Nr. 104. 07.05. Lwow - Lemberg [In Polish \& German]

37. «The Official Journal for the Lwowska Gazette». (1863). Nr. 115. 21.05. Lwow - Lemberg [In Polish \& German]

38. «The Official Journal for the Lwowska Gazette». (1863). Nr. 117. 23.05. Lwow - Lemberg [In Polish \& German]

39. «The Official Journal for the Lwowska Gazette». (1863). Nr. 122. 30.05. Lwow - Lemberg [In Polish \& German]

40. «The Official Journal for the Lwowska Gazette». (1863). Nr. 130. 10.06. Lwow - Lemberg [In Polish \& German]

41. «The Official Journal for the Lwowska Gazette». (1863). Nr. 260. 13.11. Lwow - Lemberg [In Polish \& German]

42. «The Official Journal for the Lwowska Gazette». (1863). Nr. 273. 28.05. Lwow - Lemberg [In Polish \&

43. Edwards, Henry Sutherland. (1865). The Private History of a Polish Insurrection, from Official and Unofficial Sources., in Two Volumes: Vol. II. London : Saunders, Otley, and Co., 66, Brook Street, W., 290. [In English]

44. Ferdinand Roeder's Theater Calendar for the year 1865. (1865). Berlin: Commissions-Verlag by W. J. Peiser. Friedrichstrasse 142., 589. [In German]

45. «Isar Gazette». (1862). Nr. 227. 18.08. [In German]

46. «Lemberg's General Gazette». (1857). Nr. 1. 02.04. [In German]

47. «New Passau's Gazette». (1853). Nr. 345. 16.12. [In German]

48. «Pressburg's Gazette». (1853). Nr. 288. 18.12. [In German]

49. «Overview». (1863). Nr. 17. 01.06. [In Polish]

50. Saltarino, S. (1895) - Artist's dictionary: biographical notes on art riders, sculptors, gymnasts, clowns, acrobats, specialties, etc.: all countries and times. - Dusseldorf: printing and publishing by Ed. Lintz, 316. [In German]

51. Schnür-Pepłowski, S. (1889) - Polish Theater in Lviv (1780-1881). - Lwow: The main warehouse in the bookshop of Gubrynowicz and Schmidt; from the «Polish Journal» Printing House, 411. [In Polish]

52. The Theater Almanac of the private Count Skarbek's Theater. Souvenir for the year 1866 dedicated to all friends of the stage in deepest reverence by Eduard Franz Schulz, prompter of the German theater, holder of the silver medal of honor. (1866). Lviv: Book printing by E. Winiarz, 46. [In German]

53. «Weekly Illustrated». Volume I. Lviv, The Huttemann's Circus: Władysław Zawadzki, the Correspondent of «W.I.». (1868). Nr. 8. 22.02. Warsaw [In Polish] German]

54. «Vienna's Theater Post». Magazine for theater, music, club interests. (1866). Nr. 11. 20.04. Vienna [In 55. «Vienna’s Theater Gazette». (1860). Nr. 121. 25.05. Vienna [In German]

Стаття надійшла до редакиії 26.02.2019 p. 